\title{
URGENSI PENYERAGAMAN POLA KOMUNIKASI ACCOUNT REPRESENTATIVE DAN PERANNYA DALAM PENINGKATAN EFEKTIVITAS PENGAWASAN KEPATUHAN PAJAK Mas Eko Affandi
}

\author{
Direktorat Jenderal Pajak, Jakarta. Email: mas.affandi@pajak.go.id atau me.affandi@gmail.com
}

\section{ABSTRACT}

The low level of completion of SP2DK, which has an important function in fostering and monitoring taxpayers as a mechanism to increase voluntary taxpayer compliance become the reason for this paper. The low completion of SP2DK during the pandemic is thought to have arisen not only because the economic downturn but also due to ineffective communication problems in counseling activities. Using a qualitative research method with a phenomenological approach, the study utilizes several secondary data such as education level, psychology test results, and also primary data from survey results and in-depth interviews with Account Representatives. Research seeks to identify communication problems that arise from counseling activities. The results of research that found problems related to Account Representative communication competence suggest the urgency of uniforming communication patterns in counseling activities as an effective communication guide as well as mechanism to leverage Account Representative communication competence.

Keywords: voluntary compliance, communication competence, communication pattern, counseling

\section{ABSTRAK}

Tulisan ini dilatarbelakangi rendahnya tingkat penyelesaian SP2DK yang memiliki fungsi penting dalam pembinaan, penelitian dan pengawasan Wajib Pajak melalui mekanisme himbauan untuk meningkatkan kepatuhan sukarela Wajib Pajak. Rendahnya penyelesaian SP2DK di masa pandemi tersebut diduga tidak hanya timbul karena kondisi perekonomian yang sedang mengalami penurunan tetapi juga terkait permasalahan komunikasi yang kurang efektif dalam kegiatan konseling. Menggunakan metode penelitian kualitatif dengan pendekatan fenomenologi, penelitian memanfaatkan beberapa data sekunder seperti tingkat pendidikan, hasil psikotes, dan juga data primer dari hasil survei serta wawancara mendalam dengan Account Representative. Penelitian berupaya mengidentifikasi permasalahan komunikasi yang muncul dari kegiatan konseling. Hasil penelitian yang menemukan permasalahan sehubungan dengan kompetensi komunikasi Account Representative melihat urgensi penyeragaman pola komunikasi Account Representative dalam kegiatan konseling sebagai panduan komunikasi yang efektif sekaligus berfungsi menjadi daya ungkit kompetensi komunikasi Account Representative.

Kata kunci: kepatuhan sukarela, kompetensi komunikasi, pola komunikasi, konseling 


\section{PENDAHULUAN}

\subsection{Latar Belakang}

Sejak dideteksi pada bulan Maret 2020, pandemi COVID-19 di Indonesia telah menimbulkan pengaruh sangat besar pada sektor kesehatan maupun sektor ekonomi. Perkembangan ekonomi melambat sehingga berdampak langsung pada turunnya penerimaan pajak. Hingga akhir September 2020, penerimaan pajak nasional tercatat baru mencapai 751 triliun rupiah. Dibandingkan dengan periode yang sama pada tahun sebelumnya yang mencapai 904 triliun rupiah, terjadi pertumbuhan negatif sebesar -17,01\%. Kantor Wilayah Direktorat Jenderal Pajak Sulawesi Utara, Tengah, Gorontalo dan Maluku Utara (Kanwil DJP Suluttenggomalut) juga mengalami kontraksi capaian penerimaan pajak dalam angka yang tidak jauh berbeda, yaitu sebesar $-11,75 \%$. Sampai dengan September 2020, penerimaan pajak mencapai 5,56 triliun rupiah sementara pada tahun sebelumnya mencapai 6,31 triliun rupiah. Kontraksi penerimaan pajak tersebut menunjukkan beratnya tantangan yang dihadapi DJP dalam mengamankan penerimaan pajak dalam kondisi pandemi. Mendorong perbaikan administrasi perpajakan untuk memperkuat upaya pengamanan penerimaan pajak menjadi sangat penting dalam rangka menghadapi tantangan tersebut.

Berdasarkan rekomendasi hasil diagnosis atas administrasi perpajakan (Tax Administration Diagnostic Assessment Tool) yang dilaksanakan Direktorat Jenderal Pajak pada tahun
2017, salah satu area penting yang memerlukan perbaikan administrasi adalah dukungan kepada Wajib Pajak dalam peningkatan kepatuhan sukarela. Oleh karena itu, upaya penguatan proses bisnis pengawasan Wajib Pajak yang melibatkan Account Representative perlu dijadikan prioritas. Dalam sistem pemungutan pajak self assessment upaya penguatan proses bisnis pengawasan memiliki peran penting dalam upaya deteksi dini ketidakpatuhan Wajib Pajak. Upaya tersebut dilakukan melalui mekanisme permintaan penjelasan dan/atau keterangan sebagaimana diatur dalam Surat Edaran Direktur Jenderal Pajak Nomor SE-39/PJ/2015 tentang Pengawasan Wajib Pajak dalam Bentuk Permintaan Penjelasan atas Data dan/atau Keterangan dan Kunjungan (Visit) kepada Wajib Pajak.

Menurut hasil penelitian atas data Surat Permintaan Penjelasan atas Data dan/atau Keterangan (SP2DK) dan Laporan Hasil Permintaan Penjelasan atas Data dan/atau Keterangan (LHP2DK) yang diproduksi Account Representative di wilayah Kanwil DJP Suluttenggomalut selama tahun 2017 sampai dengan 2019, diperoleh informasi bahwa penyelesaian SP2DK tergolong rendah.

Masih rendahnya tingkat keberhasilan SP2DK mengindikasikan bahwa proses penyelesaian SP2DK melalui proses konseling dengan Wajib Pajak menjadi salah satu tantangan tersendiri bagi Account Representative yang diduga terjadi karena proses interaksi antara Account Representative dan Wajib Pajak dalam kegiatan konseling bersifat zero sum game.

$$
\text { Farooqui dan Niazi (2016) }
$$


Tabel 1 Penyelesaian LHP2DK

Sumber: Diolah dari Data SP2DK dan LHP2DK Kanwil DJP Suluttenggomalut

\begin{tabular}{|c|c|c|c|c|c|r|r|}
\hline \multirow{2}{*}{ Tahun } & \multirow{2}{*}{ SP2DK } & \multicolumn{4}{|c|}{ LHP2DK } & \multicolumn{3}{c|}{ Persentase LHP2DK } \\
\cline { 3 - 8 } & & Realisasi & $\begin{array}{c}\text { Tanpa } \\
\text { Realisasi }\end{array}$ & Total & Realisasi & $\begin{array}{c}\text { Tanpa } \\
\text { Realisasi }\end{array}$ & Total \\
\hline 1 & 2 & 3 & 4 & $5=3+4$ & $6=(3) /(2)$ & $7=(4) /(2)$ & $8=(5) /(2)$ \\
\hline 2017 & 87.930 & 30.339 & 17.342 & 47.681 & $34,50 \%$ & $19,72 \%$ & $54,23 \%$ \\
\hline 2018 & 132.216 & 30.048 & 30.547 & 60.595 & $22,73 \%$ & $23,10 \%$ & $45,83 \%$ \\
\hline 2019 & 100.641 & 37.216 & 42.683 & 79.899 & $36,98 \%$ & $42,41 \%$ & $79,39 \%$ \\
\hline
\end{tabular}

menjelaskan bahwa hanya satu pihak yang memperoleh keuntungan dari interaksi tersebut. Keuntungan satu pihak dalam interaksi zero sum game menjadi kerugian pihak lain sehingga jumlah keuntungan salah satu pihak dan kerugian pihak lain akan berjumlah nol.

Proses konseling SP2DK merupakan salah satu cara yang ditempuh DJP untuk menghasilkan realisasi penerimaan pajak sebesar potensi yang harus dibayar Wajib Pajak. Kompetensi komunikasi Account Representative menjadi sangat penting supaya mereka dapat menyampaikan penjelasan mengenai potensi kewajiban perpajakan yang harus dipenuhi oleh Wajib Pajak.

Rendahnya realisasi penerimaan dari penyelesaian SP2DK menjadi salah satu indikasi belum efektifnya komunikasi Account Representative. Permasalahan lain terkait komunikasi adalah belum adanya standardisasi pola komunikasi Account Representative kepada Wajib Pajak. Hal ini menyebabkan perbedaan perlakuan komunikasi yang dialami Wajib Pajak, bergantung pada kompetensi komunikasi Account Representative yang melayani Wajib Pajak tersebut. Oleh karena itu, merumuskan pola komunikasi yang efektif dalam kegiatan konseling penyelesaian SP2DK menjadi kebutuhan mendesak.

\subsection{Rumusan Masalah}

Terdapat 5 (lima) rumusan masalah yang disajikan dalam penelitian ini, yaitu:

1. Seberapa besar pengaruh komunikasi dalam proses konseling penyelesaian SP2DK?

2. Permasalahan komunikasi apa saja yang muncul dari tingkat kompetensi komunikasi Account Representative yang bervariasi?

3. Bagaimana sikap Wajib Pajak yang muncul dalam proses konseling?

Bagaimana pengaruh konten SP2DK terhadap kegiatan konseling?

4. Apa upaya yang dapat dilakukan untuk meningkatkan efektivitas komunikasi dalam kegiatan konseling?

\section{KERANGKA TEORETIS}

Dalam rangka merumuskan pola komunikasi yang efektif dalam penyelesaian SP2DK untuk meningkatkan pengawasan kepatuhan Wajib Pajak, digunakan kerangka teori dari telaah atas ketentuan perpajakan, komunikasi, kepatuhan pajak dan juga manajemen operasional. 


\subsection{SP2DK dan LHP2DK}

Berdasarkan Surat Edaran Direktur Jenderal Pajak Nomor SE-39/PJ/2015, Surat Permintaan Penjelasan atas Data dan/atau Keterangan (SP2DK) merupakan mekanisme yang diatur dalam ketentuan perpajakan dalam rangka melakukan pembinaan, penelitian, dan pengawasan terhadap pelaksanaan kewajiban perpajakan Wajib Pajak untuk meningkatkan kepatuhan Wajib Pajak. Pembinaan, penelitian, dan pengawasan tersebut dilakukan melalui permintaan penjelasan atas data dan/atau keterangan kepada Wajib Pajak terhadap dugaan belum dipenuhinya kewajiban perpajakan sesuai dengan ketentuan peraturan perundangundangan.

$$
\text { Wajib Pajak diberikan }
$$
kesempatan untuk menyampaikan tanggapan atas SP2DK secara langsung kepada Account Representative. Tanggapan tersebut dapat berupa pengakuan ataupun sanggahan terhadap kebenaran data dengan disertai bukti atau dokumen pendukung. Tanggapan dapat disampaikan secara tertulis maupun secara langsung melalui proses konseling. Dalam proses konseling terjadi interaksi dan komunikasi antara Account Representative dan Wajib Pajak. Hasil interaksi dan komunikasi tersebut selanjutnya dituangkan dalam Laporan Hasil Permintaan Penjelasan atas Data dan/atau Keterangan (LHP2DK). LHP2DK berisi informasi pelaksanaan dan hasil permintaan penjelasan atas data dan/atau keterangan yang memuat simpulan dan usulan/rekomendasi.

\subsection{Komunikasi yang Efektif}

Nieckarz (2012) menyebutkan bahwa efektivitas komunikasi tercapai bukan hanya dengan tersampaikannya pesan kepada penerima pesan, melainkan juga diukur dari tercapainya tujuan spesifik dari pengirim pesan. Oleh karena itu, Nieckarz mengingatkan pentingnya pemilihan cara

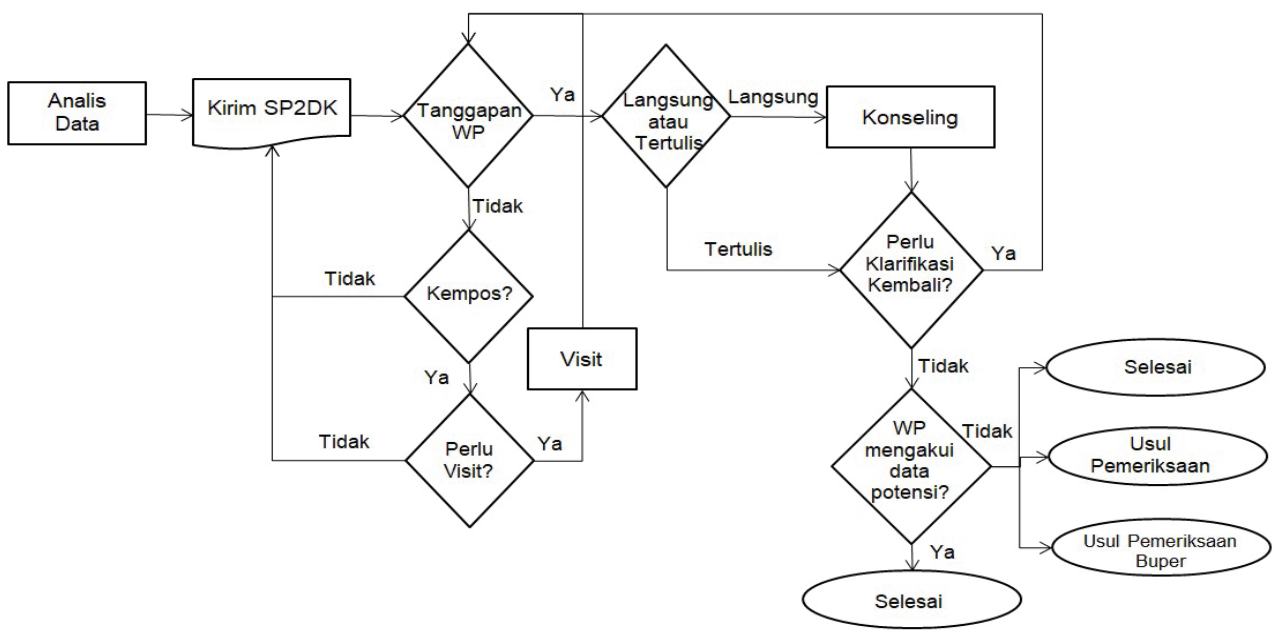

Gambar 1 Proses Penyelesaian SP2DK

Sumber: Proses SP2DK sesuai SE-39/PJ/2015 
komunikasi yang tepat, waktu yang tepat, dan penerima pesan yang tepat untuk menghindari terjadinya pengartian pesan secara keliru sehingga tujuan yang diinginkan tidak tercapai. Definisi komunikasi tersebut tidak jauh berbeda dengan konsep komunikasi berorientasi tujuan yang disampaikan oleh Goldreich et al. (2009).

Berbeda dengan Goldreich et al. (2009) yang menyampaikan pentingnya strategi, Celinska dan Nieckarz (2012) berpendapat bahwa kompetensi komunikasi menjadi faktor penting yang mempengaruhi efektivitas komunikasi. Kompetensi komunikasi merupakan kemampuan individu dalam menggunakan bahasa, menyesuaikan diri dengan situasi serta menyampaikan pesan verbal dan nonverbal dengan baik. Serupa dengan hal tersebut, Mary Munter (2009) juga menyerukan pentingnya strategi dalam interaksi komunikasi antara lain:

a. Strategi pengirim pesan (communicator strategy)

Strategi pengirim pesan merupakan strategi komunikasi yang dilakukan dengan

mengoptimalkan karakteristik pengirim pesan yang dicapai melalui penentuan tujuan dan gaya komunikasi, terdiri dari:

1) gaya komunikasi penyampaian (tell) digunakan jika tujuan yang ingin dicapai adalah penyampaian informasi kepada penerima pesan

2) gaya komunikasi persuasi (sell) digunakan jika tujuan yang ingin dicapai adalah perubahan perilaku dari penerima pesan
3) gaya komunikasi konsultasi (consult) digunakan untuk tujuan memperoleh informasi sekaligus mengarahkan penerima pesan pada tujuan yang ingin dicapai pengirim pesan

4) gaya komunikasi ajakan (join) digunakan jika pengirim pesan bertujuan untuk membuat penerima pesan mengikuti ajakan pengirim pesan

Mary Munter (2009) juga mengingatkan pentingnya kredibilitas pengirim pesan dalam tercapainya efektivitas komunikasi.

b. Strategi penerima pesan (audience strategy)

Strategi penerima pesan merupakan strategi komunikasi dengan memahami karakteristik penerima pesan, seperti apakah penerima pesan merupakan jenis penerima pesan utama atau penerima pesan kedua. Selain itu strategi ini juga dilakukan dengan memahami apa yang diketahui dan diharapkan oleh penerima pesan, serta bagaimana perasaan dan emosi mereka.

c. Strategi pesan (message strategy)

Strategi pesan merupakan strategi untuk mengorganisasi isi pesan supaya dapat mencapai tujuan yang diharapkan. Strategi tersebut dilakukan melalui penentuan fokus dan penekanan isi pesan yang ingin ditonjolkan dengan metode langsung maupun metode tidak langsung.

Strategi pemilihan jalur komunikasi (channel choice strategy)

Strategi pemilihan jalur komunikasi dilakukan melalui penentuan jalur komunikasi yang tepat. 
e. Strategi budaya (culture strategy) Strategi budaya adalah strategi komunikasi dengan memaksimalkan budaya demi tercapainya tujuan komunikasi.

Dalam studinya terkait proses komunikasi dengan pendekatan Teori Permainan, Honryo (2012) menjelaskan bahwa proses persuasi melibatkan interaksi yang saling mempengaruhi antara penyampai pesan yang menyampaikan proposal didukung rangkaian argumen dengan pengambil keputusan yang memutuskan untuk menerima atau menolak proposal. Beberapa karakteristik dinamika persuasi yang ditemukan Honryo (2012) dalam studinya antara lain:

a. Penyampai pesan mencoba meyakinkan pengambil keputusan dengan menyajikan bukti-bukti yang menarik atas sesuatu yang ditawarkan di dalam proposalnya. Penyampai pesan yang baik tidak akan mencoba melakukan persuasi kepada pengambil keputusan kecuali memiliki bukti dan argumen yang kuat untuk meyakinkan pengambil keputusan.

b. Pengambil keputusan memiliki wewenang untuk memberikan kesempatan kepada penyampai pesan untuk menyajikan bukti dan argumen ataupun untuk menunda pengambilan keputusan hingga bukti dan argumen mencukupi atau untuk menghentikan proses persuasi. Pengambilan keputusan didasarkan pada manfaat (utility) yang akan diperoleh pengambil keputusan dikurangi dengan biaya komunikasi yang terjadi. c. Proses dinamika persuasi melibatkan biaya komunikasi yang harus ditanggung baik oleh penyampai pesan maupun pengambil keputusan. Biaya komunikasi yang ditanggung penyampai pesan timbul dari upaya dalam menyiapkan bukti dan argumen. Sementara itu biaya komunikasi yang ditanggung pengambil keputusan merupakan akumulasi biaya untuk memahami bukti dan argumen dari penyampai pesan.

\subsection{Kepatuhan Pajak}

Lesmana, Panjaitan dan Maimunah (2017) menjelaskan bahwa kepatuhan pajak adalah kondisi di mana Wajib Pajak melaksanakan hak dan kewajibannya dengan baik dan tepat waktu sesuai dengan ketentuan yang berlaku. Dengan menggunakan pendekatan Teori Perilaku yang Direncanakan (Theory of Planned Behavior), mereka menemukan bahwa niat untuk patuh lebih cenderung diakibatkan oleh seberapa kuat tingkat kendali yang dimiliki Wajib Pajak dalam menampilkan perilaku tertentu serta norma individu yang timbul dalam dirinya. Alleyne dan Haris (2017) juga menemukan bahwa tingginya persepsi perilaku yang terkontrol (perceived behavior control) seorang individu akan mempengaruhi besarnya niat untuk melakukan perilaku tersebut sehingga persepsi risiko terdeteksi (perception of detection risk) sebagai salah satu persepsi perilaku yang terkontrol dalam kepatuhan pajak memiliki pengaruh signifikan terhadap kecenderungan kepatuhan Wajib Pajak. Oleh karena itu Alleyne dan Haris (2017) menyimpulkan bahwa seorang individu 
yang memiliki persepsi risiko terdeteksi rendah memiliki tingkat kemungkinan yang tinggi terlibat dalam upaya penghindaran pajak.

Menggunakan pendekatan yang sama, Razak dan Adafula (2013) memberikan temuan yang berbeda. Temuan tersebut menunjukkan bahwa sikap (attitude) Wajib Pajak merupakan salah satu faktor penting yang mempengaruhi niat Wajib Pajak terhadap kepatuhan pajak. Oleh karena itu dalam studinya Razak dan Adafula (2013) memfokuskan penelitian terhadap tiga faktor yang berhubungan dengan sikap (attitude) Wajib Pajak, yaitu: persepsi atas beban pajak (tax burden), tingkat pemahaman Wajib Pajak terhadap ketentuan pajak dan persepsi atas akuntabilitas pemerintah. Dari studi tersebut ditemukan bahwa Wajib Pajak cenderung terus patuh terhadap kewajiban perpajakannya meskipun beban pajak meningkat, sepanjang mereka merasa memperoleh manfaat dari pembayaran pajak tersebut.

\subsection{Manajemen Operasional}

Amare (2012) menyampaikan bahwa dalam rangka menciptakan konsistensi dalam kualitas suatu produk dan jasa yang dihasilkan diperlukan sebuah standar yang bertujuan untuk meminimalkan variasi, mencegah terjadinya kesalahan serta memfasilitasi tindakan perbaikan yang diperlukan. Organisasi Pengembangan Industri PBB (United Nation Industrial Development Organization) dalam kertas kerja yang diterbitkan tahun 2006 menjelaskan bahwa pada dasarnya standar adalah kesepakatan yang ditetapkan suatu organisasi yang terdisi dari persyaratan, spesifikasi teknis, ketentuan dan juga panduan proses yang bertujuan untuk mencapai tingkat yang maksimal yang diharapkan. Beberapa tujuan yang ingin dicapai melalui pembuatan standar antara lain: sesuai dengan tujuan yang diharapkan (fitness for purpose), dapat dipertukarkan (interchangeability), mengurangi variasi (variety reduction), kesesuaian (compatibility), pemanfaatan sumber daya dengan lebih maksimal (better utilization of process), dan lebih mudah dimengerti (better understanding).

Holloway et al. (1997) memberikan alternatif selain penggunaan standar yaitu pemanfaatan benchmark untuk mencapai output yang maksimal dan memastikan kualitas produk dan jasa melalui pengujian proses bisnis dan prosedur sudah berjalan dengan praktik terbaik (best practice) yang dilaksanakan oleh organisasi lain yang telah lebih dulu terbukti berhasil. Dalam menerapkan benchmark, Khrisnamoorty dan D'Lima (2014) menyampaikan bahwa organisasi perlu mengidentifikasi dan memahami faktor kunci keberhasilan dalam proses bisnisnya untuk dapat mencapai hasil yang diharapkan.

\section{METODOLOGI PENELITIAN}

Jenis penelitian yang digunakan adalah penelitian kualitatif dengan pendekatan fenomenologi. Proses penelitian bersifat induktif, dimulai dari melihat dan menganalisis fenomena banyaknya SP2DK yang tidak dapat diselesaikan dengan baik 
Tabel 2 Deskripsi Statistik Pertanyaan Survei

Sumber: Diolah dari Kuesioner yang Dibagikan kepada Account Representative

\begin{tabular}{|c|l|c|c|c|c|}
\hline No & \multicolumn{1}{|c|}{ Pertanyaan Survey } & $\begin{array}{c}\text { Jumlah Item } \\
\text { Pertanyaan }\end{array}$ & Mean & $\begin{array}{c}\text { Standar } \\
\text { Deviasi }\end{array}$ & $\begin{array}{c}\text { Cronbach } \\
\text { Alpha }\end{array}$ \\
\hline 1 & Persepsi AR terhadap Pengaruh Komunikasi & 3 item & 4,48 & 0,57 & 0,648 \\
2 & $\begin{array}{l}\text { Persepsi AR terhadap Kompetensi Komunikasinya } \\
\text { (Communicator's Competence) }\end{array}$ & 4 item & 3,72 & 0,82 & 0,923 \\
3 & $\begin{array}{l}\text { Persepsi AR terhadap Sikap Wajib Pajak } \\
\text { (Audience's Attitude) }\end{array}$ & 4 item & 3,65 & 0,81 & 0,95 \\
4 & Persepsi AR terhadap Konten SP2DK (Message) & 4 item & 3,71 & 0,82 & 0,756 \\
\hline
\end{tabular}

oleh Account Representative hingga berkembang kepada identifikasi adanya permasalahan komunikasi Account Representative dalam kegiatan konseling. Penelitian berupaya menemukan solusi terkait permasalahan komunikasi tersebut. Teknik pengumpulan data dalam penelitian ini menggunakan metode snowball purposive sehingga kebutuhan data terus berkembang sesuai dengan tujuan yang diharapkan hingga data yang dikumpulkan dianggap memuaskan. Obyek dalam penelitian ini adalah Account Representative di wilayah Kanwil DJP Suluttenggomalut. Kuesioner dirancang menggunakan Skala Likert dan disebarkan kepada seluruh Account Representative yang bertugas di wilayah Kantor Wilayah DJP Suluttenggomalut yang meliputi 11 Kantor Pelayanan Pajak (KPP). Pertanyaan-pertanyaan

dalam kuesioner berkaitan dengan efektivitas komunikasi dalam penyelesaian SP2DK, kompetensi komunikasi Account Representative (communicator's competence), sikap Wajib Pajak (audience's attitude) yang memiliki pengaruh dalam proses komunikasi, dan konten SP2DK dalam proses konseling (message). Sejumlah 103 dari 178 kuesioner berhasil dikumpulkan kembali. Persentase jumlah responden yang mengisi dan mengumpulkan kuesioner adalah sebesar 58\%, dan berasal dari $11 \mathrm{KPP}$.

Berdasarkan hasil deksripsi statistik atas pertanyaan-pertanyaan survei diketahui bahwa seluruh variabel pertanyaan memiliki nilai mean di atas standar deviasi. Dapat disimpulkan bahwa hasil dari pertanyaan-pertanyaan tersebut sudah baik dan tidak menyebabkan bias. Keempat variabel pertanyaan diketahui seluruhnya memiliki Cronbach Alpha di atas 0,6. Hal ini mengindikasikan hasil survei reliable.

Pengumpulan data terus dilanjutkan dengan pengumpulan data sekunder berupa tingkat pendidikan dan hasil psikotes Account Representative. Untuk melengkapi data yang sudah ada, peneliti juga melakukan wawancara secara mendalam (indepth interview) kepada beberapa Account Representative untuk mengkonfirmasi hasil survei sekaligus untuk menggali informasi secara lebih mendalam permasalahan komunikasi yang dihadapi dalam proses konseling, baik terkait kompetensi komunikasi Account Representative, sikap Wajib Pajak, data dan hasil analisis yang dibahas dalam 
proses konseling maupun informasi lain yang berkaitan dengan efektivitas komunikasi dalam proses konseling SP2DK.

\section{HASIL DAN PEMBAHASAN}

Sistem pemungutan pajak self assessment memberikan kewenangan yang besar bagi Wajib Pajak untuk menghitung, membayar dan melaporkan kewajiban perpajakannya secara mandiri sebagaimana diatur dalam Pasal 12 Undang-Undang tentang Ketentuan Umum dan Tata Cara Perpajakan. Konsekuensi dari penerapan sistem pemungutan self assessment adalah penerimaan pajak sangat bergantung pada kepatuhan sukarela (voluntary compliance) Wajib Pajak. Dengan demikian pengawasan perpajakan melalui mekanisme SP2DK menjadi sangat penting. Peran penting SP2DK untuk mendorong kepatuhan sukarela Wajib Pajak sejalan dengan hasil studi Alleyne dan Haris (2017) yang didukung juga oleh studi Lesmana, Panjaitan dan Maimunah (2017) yang mengingatkan pentingnya untuk meningkatkan persepsi kontrol perilaku (perceived behavior control) Wajib Pajak. Mekanisme deteksi dini (probability of detection) atas ketidakpatuhan Wajib Pajak dari SP2DK memiliki fungsi vital sebagai alat kontrol terhadap perilaku Wajib Pajak yang berpengaruh pada kepatuhan perpajakan Wajib Pajak.

Data dan/atau keterangan terhadap dugaan belum dipenuhinya kewajiban perpajakan disampaikan dalam SP2DK merupakan output dari hasil pengawasan Account Representative terhadap kewajiban Wajib Pajak. Data dan/atau keterangan yang dihasilkan dari proses analisis data yang disebut juga data potensi merupakan representasi potensi kewajiban perpajakan yang harus dibayar oleh Wajib Pajak sehingga juga menjadi potensi penerimaan pajak. Sebagai alat kontrol perilaku, efektivitas SP2DK akan tercapai ketika fungsi SP2DK dipahami dan direspon dengan tepat oleh Wajib Pajak.

Tanggapan Wajib Pajak baik dalam bentuk tertulis maupun tatap muka tidak selalu sesuai dengan yang diharapkan. Proses konseling menjadi tahap penting bagi Account Representative untuk menjelaskan tujuan SP2DK, mengklarifikasi data potensi dan meyakinkan Wajib Pajak memenuhi kewajiban perpajakannya. Sebagai sebuah proses kunci dalam penyelesaian SP2DK, Surat Edaran Direktorat Jenderal Pajak Nomor SE-39/PJ/2015 tidak memberikan panduan yang cukup detail terkait pola komunikasi dalam kegiatan konseling sehingga efektivitas komunikasi sangat tergantung pada kompetensi komunikasi masing-masing Account Representative, sikap Wajib Pajak selama proses konseling, serta data potensi yang diklarifikasi.

\subsection{Pengaruh Komunikasi dalam Efektifitas Proses Konseling}

Interaksi komunikasi yang terjadi dalam kegiatan konseling yang melibatkan Account Representative dan Wajib Pajak bersifat sangat dinamis. Berdasarkan data hasil survei yang tersaji dalam Grafik 1, 

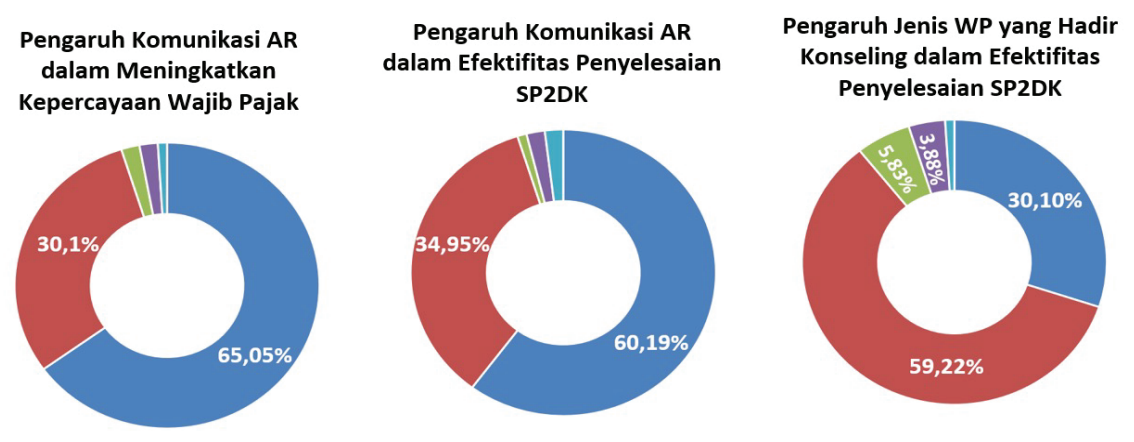

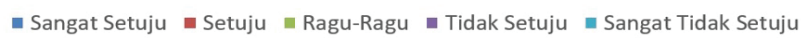

Grafik 1 Persepsi Account Representative terhadap Pengaruh Komunikasi

Sumber: Diolah dari Hasil Survei

komunikasi Account Representative terbukti memiliki pengaruh penting baik dalam meningkatkan kepercayaan Wajib Pajak maupun dalam meningkatkan efektivitas penyelesaian SP2DK. Hal ini terlihat dari persepsi Account Representative yang memberikan jawaban 'sangat setuju' dan 'setuju' sebesar 95,15\% terhadap adanya pengaruh komunikasi dalam meningkatkan kepercayaan Wajib Pajak dan sebesar 95,14\% terhadap pengaruh komunikasi dalam efektivitas penyelesaian SP2DK.

Hasil survei tersebut tidak jauh berbeda dengan hasil wawancara mendalam yang dilakukan kepada beberapa Account Representative. Dari 10 orang responden, seluruhnya menjawab bahwa komunikasi yang baik sangat penting dalam menyelesaikan SP2DK. Salah satu Account Representative mengatakan, "Komunikasi yang baik sangat penting karena meskipun data yang diklarifikasi sudah kuat tapi ketika komunikasi tidak berlangsung baik maka ada risiko tidak semua data dan potensi tersampaikan dengan baik dan dimengerti oleh WP sehingga upaya meyakinkan WP untuk melakukan pembetulan SPT dan juga pembayaran akan lebih sulit".

Berdasarkan Grafik 1 terlihat bahwa selain kemampuan komunikasi Account Representative, jenis Wajib Pajak yang hadir dalam proses konseling juga mempengaruhi efektivitas komunikasi dalam kegiatan konseling. Sebanyak 10 (sepuluh) orang Account Representative menghadapi kesulitan yang berbeda dalam menangani Wajib Pajak dalam proses konseling. Dari 10 (sepuluh) orang tersebut, 6 (enam) orang merasakan kesulitan saat menangani konsultan pajak, (tiga) 3 orang merasakan kesulitan ketika menangani Wajib Pajak Usaha Mikro, Kecil, dan Menegah (UMKM) yang memiliki pengetahuan perpajakan yang minimal, dan 1 (satu) orang merasakan kesulitan dalam menghadapi pegawai dari Wajib Pajak. Salah satu Account Representative yang mengalami suatu kesulitan dalam menghadapi para konsultan pajak menyampaikan, "Dari pengalaman saya konseling bersama konsultan, admin pajak (pegawai), direksi, owner. 
Konsultan pajak cenderung resisten dan tidak kooperatif serta semaksimal mungkin berupaya untuk menggugurkan data potensi yang kita klarifikasi. Pegawai dari Wajib Pajak cenderung kooperatif tetapi tidak memiliki wewenang mengambil keputusan. Sedangkan bila yang hadir adalah direksi, terkadang kesulitannya mereka tidak memahami aspek perpajakan sama sekali karena hanya paham pada proses bisnis usaha mereka. Sedangkan bila berhadapan dengan owner, biasanya mereka secara garis besar memahami apa yang terjadi dan mereka bisa mengambil keputusan untuk bayar atau tidak". Hasil penelitian menunjukkan bahwa perbedaan karakteristik jenis Wajib Pajak memberikan implikasi terkait kebutuhan respon atau antisipasi yang berbeda dari Account Representative.

\subsection{Kompetensi Komunikasi Account Representative}

Penggunaan pola komunikasi yang tepat dalam proses konseling menjadi sangat penting demi tercapainya tujuan SP2DK. Tidak adanya pola komunikasi yang baku menyebabkan pola komunikasi sangat beragam dan sangat ditentukan oleh gaya komunikasi dan kompetensi Account Representative. Seperti yang disampaikan Celinska dan Nieckarz (2012), kompetensi komunikasi menjadi faktor penting yang mempengaruhi efektivitas komunikasi karena berhubungan langsung dengan kemampuan individu dalam menggunakan bahasa dan logika serta menyesuaikan diri dalam berbagai situasi saat proses komunikasi berlangsung sehingga pesan verbal dan nonverbal dapat tersampaikan dengan baik.

Beberapa faktor yang mempengaruhi kompetensi Account Representative antara lain tingkat pendidikan, pengalaman, kecerdasan dan emosi. Kecerdasan dan emosi dapat terlihat dari hasil psikotes yang dilaksanakan oleh DJP kepada seluruh Account Representative yang secara spesifik mengukur kecerdasan, emosi dan sikap kerja. Aspek kecerdasan yang diukur dalam psikotes meliputi daya analisis, kemampuan verbal, kemampuan nonverbal, fleksibilitas berpikir dan kemampuan numerik. Hasil psikotes Account Representative selanjutnya dikategorikan dalam tiga tingkat yaitu luas, sedang, dan terbatas.

Data kepegawaian Kanwil DJP Suluttenggomalut sebagaimana disajikan dalam Tabel 3 menunjukkan bahwa terdapat 51 (atau sejumlah 29\%) dari total 178 Account Representative yang memiliki pendidikan di bawah Diploma 3, bahkan 7 (tujuh) orang di antaranya hanya memiliki pendidikan SMA. Hasil psikotes mengungkapkan bahwa terdapat 30 (atau sejumlah 17\%) Account Representative teridentifikasi memiliki hasil psikotest 'terbatas', 30\% memiliki hasil 'sedang' dan hanya 53\% yang memiliki hasil 'luas'.

$$
\text { Masih adanya Account }
$$

Representative dengan tingkat pendidikan di bawah Diploma 3 tidak sesuai dengan Keputusan Menteri Keuangan Nomor 188/KM.1/2017 yang mensyaratkan pendidikan minimal adalah Diploma 3. Persyaratan pendidikan minimal tersebut pada dasarnya ditetapkan untuk 
Tabel 3 Tabel Tingkat Pendidikan dan Hasil Psikotes Accout Representative

Sumber: Diolah dari Data Kepegawaian Kanwil DJP Suluttenggomalut

\begin{tabular}{|l|r|r|r|r|r|r|r|}
\hline Pasil Psikotest & SMA & D1 & D3 & S1/D4 & S2 & Jumlah & \% \\
\hline Terbatas & 3 & 4 & 6 & 17 & - & 30 & $17 \%$ \\
\hline Sedang & 3 & 15 & 11 & 22 & 2 & 53 & $30 \%$ \\
\hline Luas & 1 & 25 & 13 & 56 & - & 95 & $53 \%$ \\
\hline
\end{tabular}

memastikan kompetensi Account Representative dalam melakukan pengawasan Wajib Pajak.

$$
\text { Tugas berat }
$$

Account

Representative dalam melakukan pengawasan kepatuhan perlu ditunjang dengan persyaratan hasil psikotes minimal 'sedang'. Hal ini dimaksudkan untuk memastikan bahwa Account Representative memiliki empat elemen utama dalam kemampuan komunikasi sebagaimana disebutkan Celinska dan Nieckarz (2012), yaitu: pengetahuan dasar komunikasi, penguasaan aturan dan norma sosial, kecerdasan dalam menggunakan teknik komunikasi, dan penyesuaian diri terhadap situasi serta komitmen yang baik dalam berkomunikasi.

Mempertimbangkan tingkat pendidikan Diploma 3 sebagai syarat pendidikan minimal sebagaimana dipersyaratkan dalam Keputusan Menteri Keuangan Nomor 188/KM.1/2017 dan hasil psikotes 'sedang' sebagai persyaratan kompetensi dasar Account Representative, hanya ada 104 (atau sebesar 58\%) Account Representative di wilayah Kanwil DJP Suluttenggomalut yang memiliki kelayakan kompetensi dasar, sedangkan sebanyak 74 Account Representative ttidak memenuhi. Permasalahan kompetensi dasar tentu memiliki implikasi terhadap kualitas konseling dalam rangka penyelesaian SP2DK.

Pengaruh kompetensi dasar Account Representative terhadap efektivitas konseling tergambar dalam hasil survei dalam Grafik 2. Berdasarkan hasil survei yang mengukur langsung persepsi Account Representative terkait kompetensinya dalam komunikasi menunjukkan bahwa sebanyak 82,53\% menyatakan 'setuju' dan 'sangat setuju' bahwa mereka memiliki kemampuan untuk menyampaikan maksud dan tujuan SP2DK dalam konseling dengan baik. Akan tetapi tingkat kepercayaan diri tersebut menurun ketika mereka ditanya tentang kemampuan menjawab sanggahan Wajib Pajak. Hanya sebesar 74,75\% Account Representative yang memiliki kepercayaan diri, sementara sebesar 25,25\% menyatakan tidak.

Persentase Account Representative yang tidak percaya diri semakin meningkat hingga 33,98\% ketika ditanya mengenai kemampuan komunikasi mereka dalam meyakinkan Wajib Pajak untuk melakukan pembayaran. Kesulitan ini diakui oleh seluruh Account Representative yang menjadi responden dalam wawancara mendalam. Salah satu tanggapan Account Representative tersebut adalah, "Tantangan paling susah adalah meyakinkan WP untuk membayar 


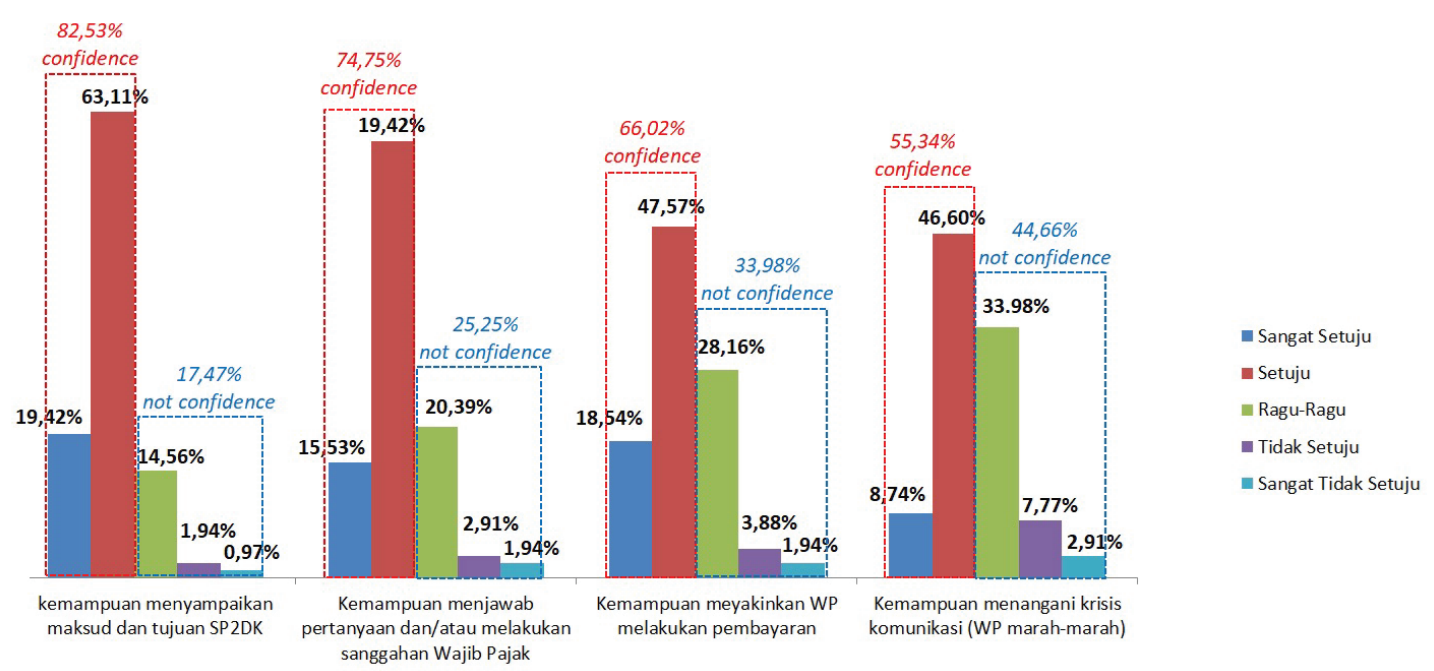

Grafik 2 Persepsi Account Representative terhadap Kompetensi Komunikasinya Sumber: Diolah dari Hasil Survei

karena meskipun data sudah valid dan tidak ada sanggahan, WP belum pasti mau bayar atas potensi tersebut sehingga meyakinkan WP bayar memang menjadi ujung penting dari proses konseling". Upaya meyakinkan Wajib Pajak untuk membayar kewajiban perpajakan yang belum dipenuhi semakin berat di masa pandemi, sebagaimana dinyatakan oleh salah satu Account Representative sebagai berikut: "Saat ini yang tersulit adalah proses meyakinkan WP mau bayar. Hal ini karena permasalahan cash flow yang dihadapi WP dan juga kondisi COVID-19 yang menyebabkan banyak usaha WP menurun".

Hasil survei juga menunjukkan bahwa salah satu tantangan tersulit dalam menangani krisis komunikasi terjadi ketika menghadapi kemarahan Wajib Pajak. Hal ini memiliki tingkat kesulitan lebih tinggi dibandingkan meyakinkan Wajib Pajak untuk melakukan pembayaran. Data survei menunjukkan bahwa hanya 55,34\%
Account Representative yang memiliki kepercayaan diri dapat menangani krisis komunikasi tersebut, sementara sebesar 44,66\% menyatakan tidak percaya diri.

$$
\text { Hasil tersebut menunjukkan }
$$
adanya risiko tidak tercapainya tujuan awal kegiatan konseling karena proses klarifikasi data dihentikan sementara saat terjadi krisis komunikasi. Jika komunikasi berhenti di tengah kegiatan konseling karena berbagai sebab maka manfaat (utility) yang diperoleh Account Representative sebesar minus biaya komunikasi yang dikeluarkan. Biaya komunikasi meliputi seluruh upaya yang dilakukan Account Representative untuk mempersiapkan proses konseling, termasuk waktu dan tenaga yang dikeluarkan. Manfaat yang diperoleh Wajib Pajak pun sebesar minus biaya komunikasi yang dikeluarkannya, meliputi waktu yang digunakan untuk konseling dan biaya kognitif untuk memahami penjelasan Account Representative.

Risiko tidak dilanjutkannya proses klarifikasi data potensi saat menangani 
krisis komunikasi semakin besar jika Account Representative tidak memiliki kematangan emosi yang baik. Oleh karena itu Account Representative dengan nilai psikotes rendah memerlukan perhatian khusus sebab mereka memiliki tingkat stabilitas emosi, kepercayaan diri, penyesuaian diri, toleransi dan kedewasaan yang rendah. $\mathrm{Hal}$ tersebut diperlukan sebagai langkah mitigasi atas risiko hilangnya potensi pajak dari tidak tertanganinya krisis komunikasi dalam proses konseling karena kematangan emosi yang kurang baik.

\subsection{Sikap Wajib Pajak dalam Proses Konseling}

Sikap Wajib Pajak sebagai penerima pesan (audience) merupakan faktor penting yang mempengaruhi tingkat efektivitas komunikasi dalam proses konseling, sebagaimana ditunjukkan pada Grafik 1. Honryo (2012) menyampaikan bahwa dalam dinamika persuasi seperti dalam proses konseling, Wajib Pajak sebagai penerima pesan juga memiliki peran sebagai pengambil keputusan. Dalam proses konseling dengan Account Representative, Wajib Pajak memiliki tiga pilihan yaitu: mengakui data potensi yang diklarifikasi (approve), menyanggah data potensi dan menolak kewajiban perpajakan yang diklarifikasi (reject), serta melanjutkan atau tidak melanjutkan proses konseling (continue or not continue).

Salah satu unsur penting yang menjadi pertimbangan sikap Wajib Pajak sebagai penerima pesan dalam pengambilan keputusan menurut Mary Munter (2009) adalah kredibilitas. Kredibilitas tercermin dari kepercayaan yang muncul dalam diri penerima pesan yang berpengaruh terhadap persepsinya saat berkomunikasi dengan pengirim pesan. Kredibilitas yang muncul sejak awal (initial credibility) menjadi modal dasar Account Representative untuk lebih mudah menyampaikan penjelasan kepada Wajib Pajak sekaligus meyakinkan mereka untuk memenuhi seluruh kewajiban perpajakan. Kredibilitas awal dapat berasal dari kesan pertama yang baik, yang dapat dimunculkan dari penampilan atau sambutan awal kepada Wajib Pajak.

Berdasarkan hasil survei terhadap Account Representative sebagaimana tersaji dalam Grafik 3 tampak bahwa hanya 66,99\% yang percaya bahwa mereka dapat memperoleh kepercayaan dari Wajib Pajak sedangkan 33,01\% masih merasa perlu membangun kredibilitas (acquired credibility) selama proses konseling. Membangun kredibilitas dalam sebuah proses komunikasi tentu tidak mudah apabila kredibilitas yang dimiliki sejak awal kurang baik.

Hal lain yang mempengaruhi efektivitas proses konseling adalah pemahaman Wajib Pajak terkait tujuan SP2DK atau tujuan diundangnya Wajib Pajak dalam proses konseling. Proses konseling akan jauh lebih lancar ketika Wajib Pajak yang hadir sudah memahami tujuan tersebut sehingga ketika proses konseling dimulai kedua pihak dapat segera fokus dalam pembahasan klarifikasi data potensi. Hasil survei menunjukkan bahwa hanya sebesar 70,88\% percaya bahwa Wajib Pajak sudah memahami tujuan SP2DK ketika 


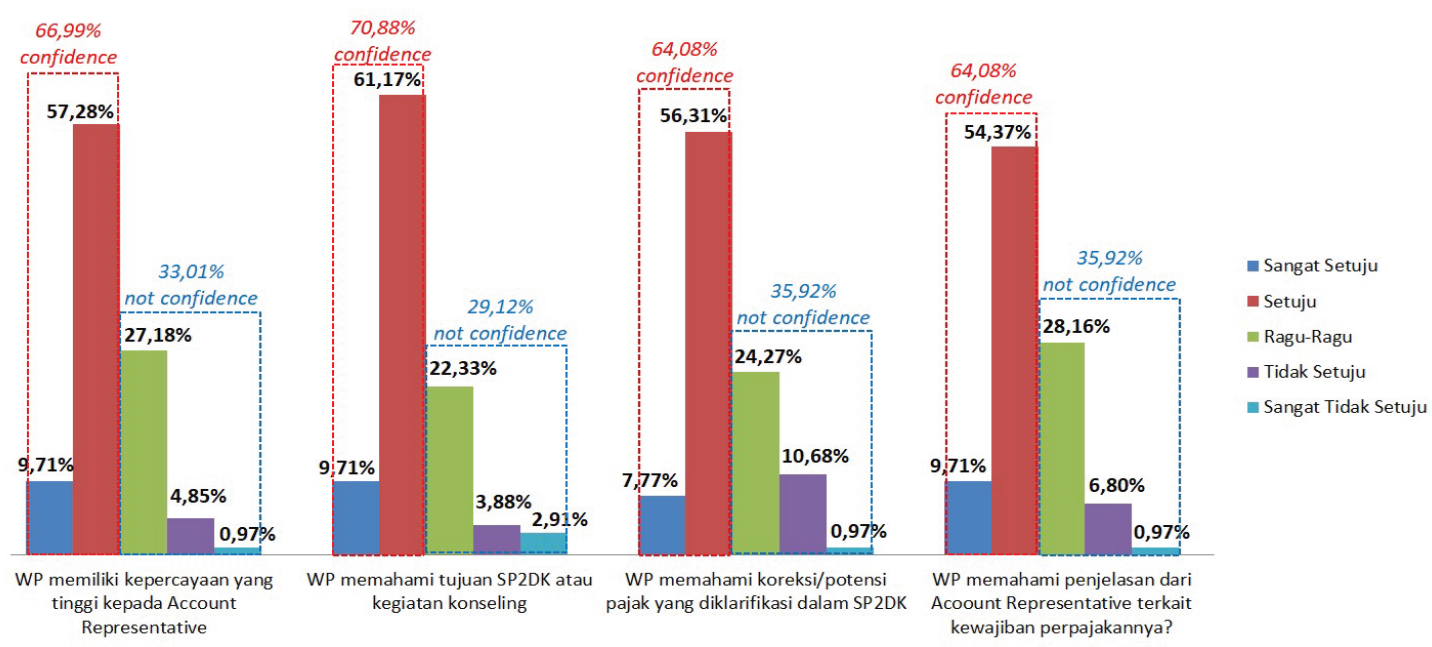

Grafik 3 Persepsi Account Representative terhadap Sikap Wajib Pajak Sumber: Diolah dari Hasil Survei

menghadiri konseling, sementara sisanya tidak.

Selain permasalahan terkait pemahaman Wajib Pajak terhadap maksud dan tujuan SP2DK juga ada permasalahan pemahaman terhadap koreksi yang diklarifikasi dalam SP2DK. Terlihat 35,92\% Account Representative tidak meyakini bahwa Wajib Pajak memahami hal tersebut. Dalam wawancara mendalam, salah satu Account Representative menyampaikan bahwa memberikan pemahaman dasar atas koreksi atau potensi pajak atas data berbentuk analisis mandiri menjadi tantangan tersendiri. Sulitnya penyampaian data potensi yang berasal dari analisis mandiri ini terjadi karena karakteristik data potensi yang kompleks karena berasal dari hasil analisis yang melibatkan analisis laporan keuangan, penyandingan data dan telaah beberapa ketentuan perpajakan sehingga informasi yang disampaikan kepada Wajib Pajak sangat banyak. Banyaknya informasi tersebut berpotensi menyulitkan Wajib Pajak dalam memahami dan merespon data potensi yang disampaikan oleh Account Representative.

Permasalahan sulitnya Wajib Pajak dalam memahami koreksi atau potensi pajak yang diklarifikasi dalam SP2DK berpengaruh langsung terhadap tingkat kesulitan dalam memberikan penjelasan kepada Wajib Pajak. Tidak tersampaikannya dengan baik penjelasan atas koreksi atau data potensi menunjukkan kegagalan fungsi SP2DK sebagai mekanisme edukasi dan bimbingan Direktorat Jenderal Pajak dalam rangka meningkatkan kepatuhan sukarela.

\subsection{Konten SP2DK dalam Proses Konseling}

Konten SP2DK merupakan bahan baku penting dalam proses komunikasi yang terjadi selama konseling berlangsung karena memiliki fungsi sebagai topik utama dalam dinamika komunikasi antara 
Account Representative dengan Wajib Pajak. SP2DK berisi data porensi yang belum dilaporkan Wajib Pajak atau kewajiban perpajakan yang belum dipenuhi oleh Wajib Pajak. Hasil survei yang tersaji dalam Grafik 4 menunjukkan bahwa 96,12\% Account Representative menyatakan 'setuju' dan 'sangat setuju' atas pernyataan bahwa jenis data potensi memiliki pengaruh terhadap efektivitas proses konseling dalam penyelesaian SP2DK.

Seluruh Account Representative yang diwawancara menyepakati adanya pengaruh jenis data terhadap efektivitas proses konseling. Salah satu Account Representative dalam wawancara lebih lanjut menjelaskan sebagai berikut, "Menurut saya, jenis data sangat berpengaruh dalam proses konseling. karena data konkret bisa meningkatkan kepercayaan diri saya dalam proses konseling, sedangkan data dari hasil analisis terkadang saya masih ragu menyampaikannya ke Wajib Pajak karena saya kadang mengalami kesulitan ketika menghadapi pertanyaan balik dari WP tentang dasar perhitungan dan dasar hukumnya". Berdasarkan penjelasan Account Representative tersebut terungkap bahwa jenis data potensi yang diklarifikasi juga memiliki kompleksitas yang berbeda-beda. Semakin kompleks informasi dalam data potensi, semakin tidak mudah bagi Account Representative untuk menjelaskan dan meyakinkan kewajiban perpajakan.

Sebagaimana terlihat dalam Grafik 4, nilai potensi pajak juga memiliki pengaruh terhadap efektivitas konseling meskipun dalam persentase yang lebih rendah. Sebanyak 78,64\% Account Representative menyatakan 'setuju' dan 'sangat setuju' terhadap pernyataan tersebut. Hal ini wajar mengingat nilai potensi mencerminkan nilai yang harus dibayar oleh Wajib Pajak ketika mengakui data potensi yang diklarifikasi oleh Account Representative.

Hasil survei menunjukkan bahwa sejumlah 66,02\% Account Representative menyatakan 'setuju' dan 'sangat setuju' bahwa konten SP2DK mampu memenuhi

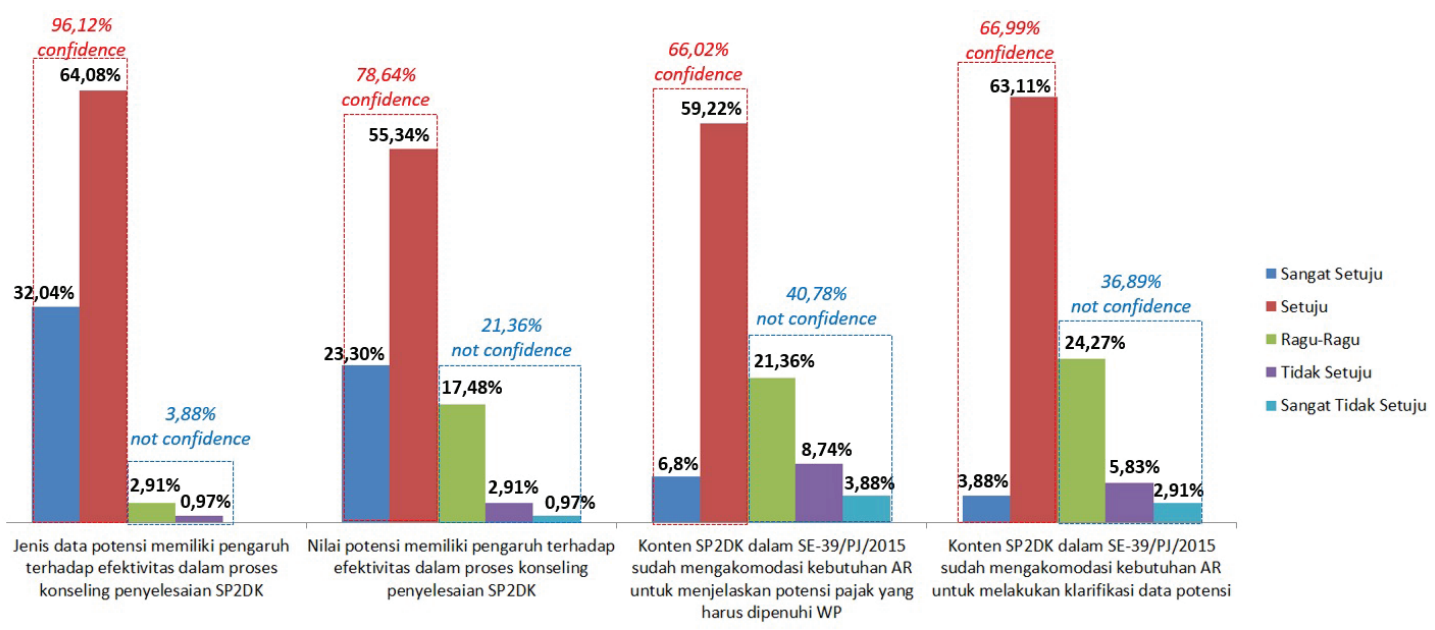

Grafik 4 Persepsi Account Representative terhadap Konten SP2DK Sumber: Diolah dari Hasil Survei 
tujuannya dalam menjelaskan potensi pajak yang harus dipenuhi Wajib Pajak. Dalam persentase yang tidak jauh berbeda, sejumlah 66,99\% Account Representative menyatakan 'setuju' dan 'sangat setuju' bahwa konten SP2DK mampu mengakomodasi kebutuhan untuk melakukan klarifikasi data porensi.

Dalam wawancara, salah satu Account Representative menyampaikan bahwa dia seringkali melampirkan tambahan perhitungan data potensi yang lebih rinci dan mudah dimengerti Wajib Pajak ataupun rincian daftar pertanyaan yang harus diklarifikasi oleh Wajib Pajak. Lembar tambahan atas format SP2DK yang telah ada tersebut berguna untuk memperjelas dasar perhitungan potensi atas jenis data yang kompleks. Meskipun hal itu berarti menambah waktu dan upaya, tambahan perhitungan dan daftar pertanyaan tersebut dapat berfungsi sebagai daya ungkit untuk meningkatkan kekuatan persuasi SP2DK, senada dengan yang disampaikan Honryo (2012) bahwa hanya pesan yang memiliki biaya (costly message) yang memiliki kekuatan persuasi.

\subsection{Upaya Meningkatkan Efektivitas Komunikasi dalam Kegiatan Konseling}

Hasil survei mengungkapkan berbagai permasalahan komunikasi yang berpengaruh terhadap efektivitas penyelesaian SP2DK. Sehubungan dengan hal tersebut, merumuskan upaya untuk meningkatkan efektivitas komunikasi dalam kegiatan konseling yang mampu memitigasi permasalahan komunikasi yang muncul menjadi penting. Penyeragaman pola komunikasi sebagai standar dapat menjadi alternatif solusi. Amare (2012) menyebutkan bahwa standar mampu berfungsi sebagai panduan sekaligus meminimalkan variasi, mencegah terjadinya kesalahan, serta memfasilitasi tindakan perbaikan yang diperlukan. Oleh karena itu, penyeragaman pola komunikasi bertujuan untuk menciptakan konsistensi kualitas penyelesaian SP2DK dan memberikan persamaan pelayanan (equal treatment) untuk seluruh Wajib Pajak. Sesuai dengan rekomendasi Organisasi Pengembangan Industri PBB (United Nation Industrial Development Organization), penyeragaman pola komunikasi dalam proses bisnis konseling diharapkan dapat memberikan manfaat sebagaimana dalam penerapan standar untuk industri, antara lain:

a. Sesuai dengan tujuan yang diharapkan (fitness for purpose)

Penyeragaman pola komunikasi diharapkan memberikan panduan mengenai pola komunikasi yang tepat untuk mencapai tujuan penyelesaian SP2DK.

b. Dapat dipertukarkan (interchangeability) Penerapan pola komunikasi yang seragam menjamin kualitas saat terjadi pergantian Account Representative

c. Mengurangi variasi (variety reduction) Penyeragaman pola komunikasi diharapkan memastikan standar kualitas konseling sehingga terjadi perlakuan yang sama (equal treatment). 
d. Pemanfaatan sumber daya lebih maksimal (better utilization of process)

Pola komunikasi yang seragam diharapkan dapat memperpendek waktu yang diperlukan dalam proses konseling penyelesaian SP2DK.

e. Lebih mudah dimengerti (better understanding)

Standardisasi pola komunikasi diharapkan dapat menjadikan proses konseling lebih mudah dipahami oleh Wajib Pajak.

Standar pola komunikasi selain membawa beberapa manfaat teknis tersebut, diharapkan juga mampu menjadi daya ungkit (leverage) kompetensi komunikasi Account Representative. Hal tersebut merupakan langkah untuk memitigasi risiko terjadinya permasalahan kompetensi dasar seperti tingkat pendidikan serta kecerdasan dan kematangan emosional melalui panduan pola komunikasi yang jelas untuk setiap situasi komunikasi yang berbeda.

adalah

Hal lain yang tidak kalah penting komunikasi yang tepat sebagaimana disampaikan Goldreich et al. (2009). Pemanfaatan strategi komunikasi yang tepat dilaksanakan melalui proses sensing untuk menilai situasi yang dihadapi dalam proses komunikasi baik pada saat persiapan maupun pada saat proses komunikasi berjalan. Pemahaman karakteristik Wajib Pajak menjadi pertimbangan awal yang penting dalam menyusun strategi komunikasi yang baik. Mary Munter (2009) menjelaskan pentingnya strategi penerima pesan (audience strategy) untuk mengetahui siapa penerima pesan yang dihadapi, apa preferensinya dan bagaimana harapan dan emosi yang mereka rasakan. Hal tersebut penting untuk menentukan pendekatan terbaik untuk berkomunikasi dengan Wajib Pajak. Pendekatan komunikasi yang disampaikan kepada penerima pesan utama (primary audience) yaitu Wajib Pajak dengan pendekatan yang dilakukan jika berkomunikasi dengan penerima pesan kedua (secondary audience) seperti pegawai atau konsultan Wajib Pajak tentu berbeda. Memahami budaya dan bahasa daerah yang digunakan Wajib Pajak juga dapat membantu meningkatkan efektivitas komunikasi melalui pendekatan strategi budaya (cultural strategy).

Penilaian kredibilitas Account Representative dalam proses konseling juga harus dipertimbangkan dalam penyusunan strategi komunikasi. Dalam situasi komunikasi di mana kredibilitas awal Account Representative tercapai, proses komunikasi dapat langsung masuk pada penjelasan tujuan SP2DK dan dilanjutkan dengan klarifikasi dan pembahasan data potensi. Akan tetapi bila hasil penilaian awal menunjukkan kredibilitas yang kurang baik maka perlu disusun sebuah pola komunikasi untuk terlebih dahulu membangun kredibilitas sebelum masuk ke bahasan pokok tentang tujuan SP2DK dan klarifikasi data potensi. Membangun kredibilitas penting dilakukan untuk membangun kepercayaan Wajib Pajak sehingga proses komunikasi berjalan lancar.

Mary Munter (2009) menjelaskan pentingnya penerapan gaya komunikasi yang berbeda untuk situasi dan tujuan 
komunikasi yang berbeda dalam rangka meningkatkan efektivitas strategi komunikasi. Gaya komunikasi penyampaian (tell) memiliki karakteristik tersampaikannya informasi secara lengkap, jelas, dan ringkas sehingga sesuai untuk diterapkan dalam penyampaian tujuan SP2DK dengan tujuan tercapainya pemahaman atas data potensi sekaligus klarifikasi atas data dan kewajiban perpajakan kepada Wajib Pajak. Gaya komunikasi konsultasi (consult) sesuai untuk tujuan mengklarifikasi data, menjawab sanggahan Wajib Pajak serta menggali data lain. Gaya komunikasi persuasi (sell) sesuai untuk tujuan terjadinya perubahan sikap Wajib Pajak. Sementara itu, gaya komunikasi ajakan (join) sesuai untuk menenangkan Wajib Pajak yang sedang berada dalam kondisi marah.

Standar pola komunikasi di samping mengatur gaya komunikasi yang sesuai dengan tujuan komunikasi, juga mempertimbangkan faktor kompetensi komunikasi Account Representative. Atas proses konseling yang dilakukan oleh Account Representative dengan tingkat kompetensi komunikasi yang rendah perlu dipertimbangkan sebuah prosedur komunikasi yang dapat memitigasi kelemahan tersebut. Prosedur komunikasi tersebut dapat dilakukan dalam bentuk pendampingan oleh Kepala Seksi sebagai atasan langsung atau oleh Account Representative yang lebih senior. Prosedur tambahan tersebut penting dilakukan terutama dalam menghadapi situasi komunikasi yang sulit dan komplek.

Hal lain yang harus diperhatikan adalah pendekatan penyampaian pesan yang disesuaikan dengan karakteristik isi pesan (message strategy). Beragamnya data potensi yang diklarifikasi dalam proses konseling memerlukan pendekatan penyampaian pesan yang juga beragam. Klarifikasi data konkret dengan tujuan pembuktian adanya transaksi yang belum dilaporkan dapat menggunakan pendekatan langsung (direct approach). Sementara itu proses yang terjadi dalam konseling atas data hasil analisis lebih kompleks karena melibatkan klarifikasi atas data analisis dibutuhkan pendekatan tidak langsung (indirect method).

Komunikasi merupakan sebuah proses yang sangat dinamis, sehingga strategi dan pola komunikasi yang digunakan juga harus dinamis. Dibutuhkan kecerdasan dalam menilai efektivitas pola komunikasi yang dijalankan melalui proses sensing untuk menilai situasi komunikasi yang dihadapi. Ada kalanya strategi komunikasi tidak berjalan sesuai harapan karena munculnya permasalahan secara tiba-tiba. Misalkan terjadi perdebatan yang melibatkan ketegangan emosi antara Wajib Pajak dan Account Representative. Pada saat-saat seperti ini proses sensing penting dilakukan untuk memahami situasi komunikasi yang terjadi dalam rangka menentukan perubahan strategi yang diperlukan untuk memitigasi permasalaha yang mungkin terjadi.

\section{KESIMPULAN DAN REKOMENDASI}

Berdasarkan hasil analisis data dan pembahasan yang telah diuraikan di atas, 


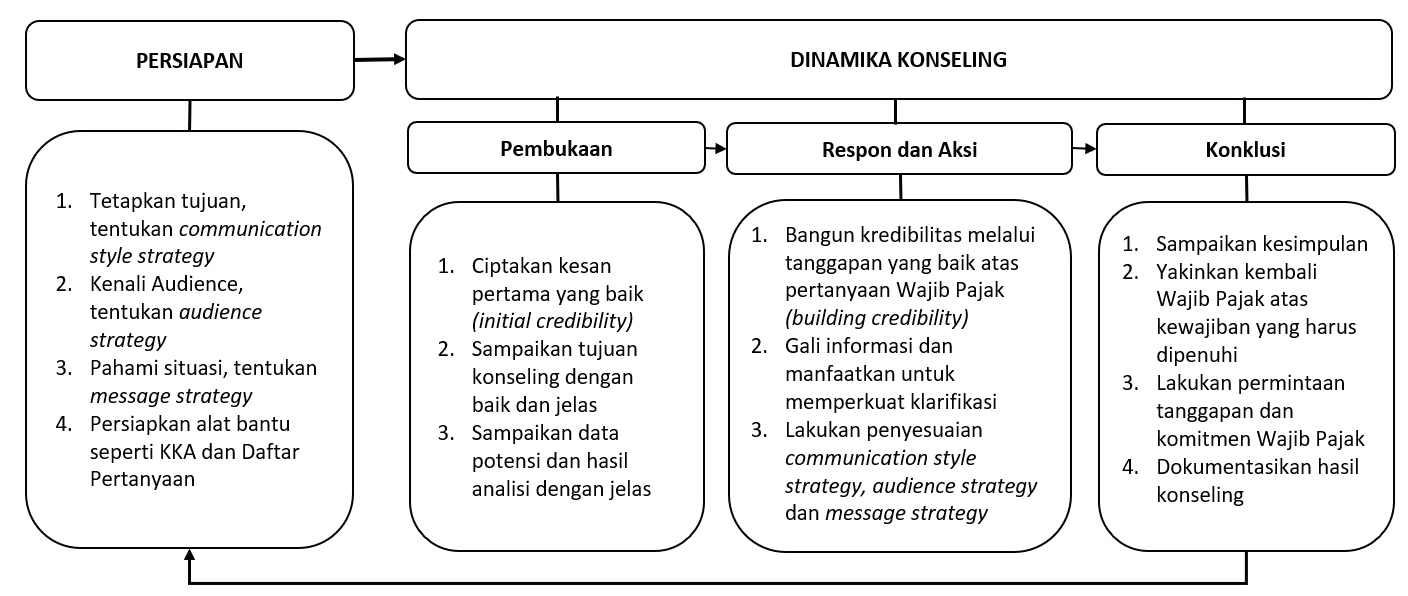

Gambar 2 Pola Komunikasi

Sumber: Konsep Pola Komunikasi Dasar Usulan Penulis

dapat disimpulkan bahwa pengawasan perpajakan dengan SP2DK yang didukung dengan kegiatan konseling memiliki fungsi penting dalam sistem pemungutan pajak self assessment sebagai deteksi dini ketidakpatuhan Wajib Pajak dalam rangka mendorong kepatuhan sukarela Wajib Pajak. Tanpa adanya panduan pola komunikasi dalam kegiatan konseling, proses komunikasi yang terjadi bersifat acak sehingga efektivitas komunikasi sangat ditentukan oleh kompetensi komunikasi Account Representative, sikap dan respon Wajib Pajak selama proses konseling, serta jenis data potensi yang diklarifikasi. Solusi

direkomendasikan

yang penyeragaman pola komunikasi sebagaimana ditampilkan dalam Gambar 2 di atas.

\section{Account Representative} diharapkan telah menetapkan tujuan komunikasi pada tahap persiapan, sehingga gaya komunikasi yang sesuai (communication style strategy) dapat ditentukan. Di samping itu, Account Representative juga diharapkan dapat mengenali pihak yang akan hadir, apakah Wajib Pajak yang bersangkutan, pegawai dari Wajib Pajak, atau konsultan. Jika informasi tersebut diketahui, Account Representative dapat mempersiapkan strategi komunikasi yang tepat sesuai dengan penerima pesan (audience strategy).

Account Representative juga perlu memahami situasi seperti jenis dan kompleksitas data sehingga strategi penyampaian pesan yang sesuai dapat ditentukan, yaitu dengan pendekatan langsung atau pendekatan tidak langsung. Hal lain yang juga dapat dipersiapkan sebagai tambahan jika diperlukan adalah kertas kerja analisis untuk membantu menjelaskan perhitungan data potensi secara rinci dan daftar pertanyaan sebagai panduan dalam menggali informasi.

\section{Account}

Representative diharapkan juga dapat menggunakan strategi komunikasi yang tepat pada tahap dinamika konseling, mulai dari tahap pembukaan, tahap respon dan aksi serta tahap konklusi. Dalam tahap pembukaan, Account Representative 
perlu menciptakan kesan pertama yang baik sehingga kredibilitas awal dapat dicapai. Setelah itu proses konseling dilanjutkan dengan menyampaikan tujuan konseling dan data potensi yang diklarifikasi dengan jelas. Setelah tahap pembukaan proses komunikasi cenderung berlangsung dengan sangat dinamis. Account Representative diharapkan mampu menjawab pertanyaan Wajib Pajak dan mengklarifikasi data dengan baik sehingga kredibilitasnya terbangun. Tahap terakhir dari proses konseling adalah Account Representative merangkum seluruh pembahasan yang terjadi antara kedua belah pihak dan menyampaikannya sebagai simpulan disertai upaya meyakinkan Wajib Pajak untuk membayar pajak terutang. Alur pola komunikasi kembali lagi ke tahap persiapan apabila proses konseling memerlukan proses klarifikasi sebagai dasar pengambilan keputusan.

Pola komunikasi di atas idealnya juga diuraikan dengan lebih rinci dengan mengadaptasi praktik pola komunikasi yang telah berjalan baik dari unit kerja dengan tingkat efektivitas penyelesaian SP2DK tinggi dengan pendekatan benchmarking untuk mencapai output yang maksimal dan memastikan kualitas produk dan jasa yang baik, sebagaimana disebutkan oleh Holloway et al. (1997). Penyeragaman pola komunikasi yang disusun dengan pendekatan praktik terbaik (best practice) tersebut diharapkan dapat menjadi panduan sekaligus daya ungkit kompetensi komunikasi Account Representative untuk meminimalkan variasi dan meningkatkan tingkat penyelesaian SP2DK.

\section{IMPLIKASI DAN KETERBATASAN}

Penelitian secara teoretis menunjukkan implikasi bahwa tanpa adanya penyeragaman pola komunikasi dan penggunaan strategi komunikasi yang tepat, proses penyelesaian SP2DK melalui kegiatan konseling menjadi kurang efektif dalam meningkatkan kepatuhan Wajib Pajak. Hasil penelitian ini juga memiliki implikasi praktis terkait perlunya penyempurnaan dalam kebijakan penyelesaian SP2DK sebagaimana diatur dalam Surat Edaran Direktur Jenderal Pajak Nomor SE-39/PJ/2015 dengan menambahkan pola komunikasi terstandar sebagai bagian proses bisnis penyelesaian SP2DK yang harus dijalankan Account Representative dalam kegiatan konseling.

Penelitian dilaksanakan dengan menggunakan data sekunder dan hasil survei kepada Account Representative di wilayah kerja Kanwil DJP Suluttenggomalut. Oleh karena itu hasil penelitian ini terbatas pada persepsi Account Representative terkait proses komunikasi yang terjadi dalam kegiatan konseling. Diperlukan penelitian lebih mendalam dengan melibatkan Wajib Pajak sebagai responden untuk memperoleh gambaran utuh permasalahan komunikasi dalam kegiatan konseling. Instrumen kuesioner yang dikembangkan Jack Gibb (1961) untuk meneliti situasi apa saja yang memicu sikap defensif atau kooperatif dalam interaksi komunikasi direkomendasikan untuk melengkapi 
pemahaman terhadap sikap resistensi Wajib Pajak dalam kegiatan konseling.

\section{DAFTAR PUSTAKA}

[1] Alleyne, P., \& Haris, T. (2017). Antecedents of taxpayers' intentions to engage in tax evasion: evidence from Barbados. Journal of Financial Reporting and Accounting, 15(1), 2-21.https://doi.org/10.1108/JFRA-122015-0107

[2] Amare, G. (2012). Reviewing the value of a standard operating procedure. Ethiopian Journal of Health Science, 22(3), 205-208. Diakses dari https://www.ncbi.nlm.nih.gov

[3] Ajzen, I. (1991). Theory of planned behavior. Organizational Behavior and Human Decesion Process, 50, 179-211. doi:10.1016/0749-5978(91)90020-T

[4] Celinska, S., \& Nieckarz, Z. (2012). Guideline for effective communication in organization. Diakses dari https://www.researchgate.net/ publication/258838578_Guidelines_ for_effective-_communication_in_an_ organization

[5] DJP. (2017). Tax administration diagnostic assessment tool.

[6] Farooqui, A. D., \& Niazi, M. A. (2016). Game theory model for communication between agents. Complex Adaptive Systems Modeling, 4(13), 1-31. https://doi.org/ 10.1186/s40294-016-0026-7

[7] Gibb, J. R. (1961). Defensive communication. Journal of Communication, 11(3), . https:// doi.org/10.1111/j.1460-2466.1961.tb00344.x

[8] Goldreich, O., Juba, B., \& Sudan, M. (2009). A theory of goal-oriented communication. http://dx.doi.org/10.1145/1993806.1993863

[9] Holloway, J. A., Hinton, C. M., Mayle, D., \& Francis, G. (1997). Why benchmark? Understanding the process of best practice benchmarking, 1-18. Diakses dari https://www.researchgate.net/publication/2 54519995_WHY_BENCHMARK_UNDERSTAN DING_THE_PROCESSES_OF_BEST_PRACTIC E_BENCHMARKING

[10] Honryo, T. (2012). Essays on communication in game theory (doctoral theses). Colombia University, 1-233. Tersedia dari Academic Commons.
[11] Khrisnamoorty, B., \& D'Lima, C. (2014). Benchmarking as a measure of competitiveness. International Journal of Process Management and Benchmarking, 4(3), 342-359. https://doi.org/ 10.1504/IJPMB.2014.063240

[12] Lesmana, D., Panjaitan, D., \& Maimunah, M. (2017). Tax compliance ditinjau dari Theory of Planned Behavior (TPB): Studi empiris pada wajib pajak orang pribadi dan badan yang terdaftar pada KPP di kota Palembang. Jurnal InFestasi, 13(2), 354-366. https://doi.org/10.21107/infestasi.v13i2.3514

[13] Munter, M. (2009). Guide to managerial communication: Effective business writing and speaking. New Jersey: Prentice Hall

[14] Razak, A. A., \& Adafula, C. J. (2013). Evaluating taxpayers attitude and its influence on tax compliance decision in Tamale Ghana. Journal of Accounting and Taxation, 5(3), 48-57. https://doi.org/ 10.5897/jat2013.0120

[15] Surat Edaran Direktur Jenderal Pajak Nomor SE-39/PJ/2015, Pengawasan Wajib Pajak Dalam Bentuk Permintaan Penjelasan atas Data Dan/Atau Keterangan, Dan Kunjungan (Visit) Kepada Wajib Pajak, 29 Mei 2015

[16] United Nation Industrial Development Organization. (2006). Role of standards, Working Paper, 6-50. Diakses dari https://www.unido.org/sites/default/files/20 09-04/Role_of_standards_0.pdf 